\title{
Human Capital and Manufacturing Output in Nigeria: A Micro-Data Survey
}

\author{
Favour Olarewaju $^{1}$, Adeyemi Ogundipe $e^{1,3}$, Paul Adekola ${ }^{2,3} \&$ Ngozi Adeleye ${ }^{1,3}$ \\ ${ }^{1}$ Economics Program, Department of Economics and Development Studies, Covenant University, Ota, Nigeria \\ ${ }^{2}$ Demography Program, Department of Economics and Development Studies, Covenant University, Ota, Nigeria \\ ${ }^{3}$ Centre for Economic Policy and Development Research (CEPDeR), Nigeria \\ Correspondence: Favour Olarewaju, Department of Economics and Development Studies, Covenant University, Ota, \\ Nigeria. Tel: 234-810-700-1789. E-mail: favourbola1@ gmail.com
}

Received: July 28, 2020

doi:10.5430/rwe.v12n2p132
Accepted: November 9, 2020

Online Published: January 17, 2021

URL: https://doi.org/10.5430/rwe.v12n2p132

\begin{abstract}
In attempting to explain the rather inconsistent growth of manufacturing industries in Nigeria, this study seeks to investigate the effect of human capital on manufacturing output in the Nigerian industrial firms. The study adopts human capital theory as a basis for the theoretical framework. Micro-data from the World Bank Enterprise Survey (2014) is utilised to perform Spearman Correlation in investigating the specific effects of HC on manufacturing value-added for Nigerian industries. High-school education, formal training and research were found to have a weak positive but significant impact on levels of manufacturing output. Therefore, recommendations on improved human capital quality via public-private partnerships, fostering trainings, research activities and conducive business environment in terms of unbiased and efficient institutions for manufacturing sectors, among others were proffered.
\end{abstract}

Keywords: manufacturing output, human capital, manufacturing value-added

\section{Introduction}

This research relates to the United Nations 2030 Sustainable Development Goal (SDG) 9 on industry, innovation and infrastructure which reinforces the need to build resilient infrastructure, promote sustainable industrialisation and foster innovation. Manufacturing industries possess potentials for elevated sustainability and are less susceptible to external shocks (Anyanwu, 2018). This is possible due to the labour-intensive and export-oriented nature of manufacturing enterprises that are receptive to capital accumulation, economies of scale, spill-over effects, linkages and technological progressions (UNIDO, 2015). Nigeria is among the key players in Africa and considered to become the next great manufacturing centre in the world as it is projected that this sector is capable of taking a large share of 100 million labour-intensive manufacturing jobs which will create vast opportunities for Nigeria in particular and Africa as a whole (Page, 2018). Hence, such opportunities give room for industrialisation through higher value-added from sales of national physical inventories of raw, semi-finished or finished goods. Thus, the manufacturing sector has proven to be of primal importance to the growth of developing nations (Onakoya, 2014; Adeleye, Osabuohien \& Asongu, 2020).

Essentially, it is asserted that improved human capital and higher labour productivity in manufacturing boosts sectorial output due to influence greater economies of large-scale production and technical progress (Thirlwall, 2013). Nonetheless, scarce evidence of structural change has been linked to Nigeria's recent growth given comparatively low industrialisation levels when compared to other countries. Historically, Nigeria particularly lags in skilled labour with paltry contribution to the manufacturing sector (Anyanwu, 2018; Adeleye et al., 2020). Such low labour productivity is regarded as a major feature of backward economies given the prevalence of high levels of illiteracy, unskilled labour and poor technical training. These inadequacies are mostly due to low living standards which induce substandard education and health (Frankema, 2015).

Furthermore, Nigeria scores low in international schooling standards as its primary, secondary and tertiary school enrolment rates average about $89 \%, 37 \%$ and 10\%, respectively in comparison to almost $100 \%$ of East Asian or OECD countries during the 1960s (National Bureau of Economic Research - NBER, 2020). This has escalated into the 'learning crises where it is posited that $56 \%$ of children within Africa, in general, will be unable to attain the 
minimum level of required proficiency at the end of their primary education. Despite increasing enrolment rates, completion rates are lower and drop-out rates are rapidly escalating. Recently, over 10.5 million children have dropped out of school in Nigeria with about $60 \%$ of this figure from Northern Nigeria (Nwokeocha, 2018; British Broadcasting Corporation - BBC, 2017). This could be indicative of retention problems as reflected by high drop-out rates which cumulate from direct sources such as poor-quality education, finance issues, as well as indirect causes including opportunity costs of household duties and earning additional income sources. The start of the twenty-first century has conceived industrialisation possibilities within the region as greater emphasis is on enhancing manpower skills compared to past import-substitution approaches. Thus, the best way forward entails promoting industrialisation by investing in research, education and health to boost labour skilfulness. Given the above, manufacturing value-added (MVA) per capita is still one of the lowest within the African continent and Nigeria, specifically. This brings the question, why has manufacturing output remained relatively low in Nigeria? Hence, this study seeks to find out why manufacturing output has shown very little improvement over time in Nigeria's industrial sector.

Extant literature on manufacturing output induced by human capital is mostly on developed nations (Crafts, 2018) including the case of OECD economies (Maroto-Sánchez \& Cuadrado-Roura, 2009). However, there are relatively few studies on selected African countries (Meagher, 2016; De Vries, Timmer \& De Vries, 2015; Adenikinju, Söderling, Soludo \& Varoudakis, 2002) such as South Africa (Fallon \& Lucas, 1998), and Nigeria (Adesugba \& Mavrotas, 2016). For instance, Anumudu (2010) explored the impact of human capital on labour productivity within manufacturing firms at Anambra and Enugu states. Nonetheless, comprehensive studies on Nigeria based on the cross-sectional analysis of manufacturing firms is rather limited - the lacuna this paper attempts to fill. In other words, the main research objective is to examine if human capital has significant impact on the manufacturing output of Nigerian firms. The contribution to existing literature hinges on the examination of the research problem while controlling for other variables that influence the output of the manufacturing sector in Nigeria. To achieve this, specific micro-data analysis using World Bank dataset (Enterprise Survey) is engaged using a "bottom-up" approach. The rest of the paper is segmented into the following: section 2 gives an overview of relevant literature; section 3 details the data and methodology; section 4 presents the results of data analysis; section 5 discusses the findings while section 6 concludes with policy recommendations.

\section{Theoretical Review of the Literature}

\subsection{Human Capital Theory}

The consensus from the human capital theory is that human capital (HC) plays an undeniable part in economic progress. This conjecture is developed by Adam Smith and Alfred Marshal most especially with regards to the quality and quantity of $\mathrm{HC}$ alongside physical capital. Therefore, human resource development has a huge likelihood of improving labour quality and productivity which in turn impacts output and wealth levels of countries. Schultz (1961a) incorporated investment in education into major economic analytical reasoning. Such that individual efforts, attitudes, skills and knowledge constitute the human capital needed to effectively coordinate and manipulate capital, technology and natural resources for optimum production. Therefore, if properly utilised and harnessed would contribute to higher levels of labour productivity.

Overall, human capital is enhanced and accumulated through diverse manners. Firstly, through formal education of pre-primary, primary, secondary and tertiary/higher education. The second dimension is via informal or systematic on-the-job or in-service training whichmight employ institutions in adult educational programs. Becker (1964) recognizes these two dimensions. The third angle entails personal self-development. However, enhancing the health of the working population through better nutrition, public health and medical programs help to increase the aggregate working capacity of workers. Lastly, human capital can be facilitated by technical expertise and educational manpower (Anumudu, 2010).

Shaffer (1961) and Schultz (1961a) criticised human capital ideologies for not distinguishing between its consumption and investment aspects. Although education might not adequately measure occupational skills due to diverse ranges of physical, cognitive and interpersonal skills (Howell \& Wolf, 1991). Arrow (1962) identifies the importance of job trainings and learning-by-doing to improve skillsets such thathuman capital conceptualisation can be segmented into two main components: industry-related skill-building involving both informal and formal training and education, and technological capacity accumulation which determines personal and institutional experience and knowledge (Lall, 1998). Though "human capital" and "skills" are often used synonymously, they are different but with interconnected concepts with "skill" having several dimensions. Skills generally refer to having mastery, expertise, exceeding performance, employment competency, the volume of capital stock accumulated (Stevens, 
1994), autonomy at work (Braverman, 1974), and effective task execution (Ash, 1988).

Cörvers (1994) identified four effects of human capital on labour productivity namely: the worker, allocative, diffusion, and research effects which supports the work of Pencavel (1991). Worker effect involves the positive marginal productivity of education based on the assumption that education raises the effectiveness of labour input and shifts production possibility curves (PPC) outwards. So, this effect is seemingly linked to the complex nature of physical production process as greater complexity increases the vacancy for workers to grow their technical efficiency of producing commodities (Welch, 1970). Notably, a higher volume of highly skilled or intermediate workers compared to low-skilled employees boost productivity outcomes of goods (Anumudu, 2010).

Meanwhile, allocative effect involves the elevated efficiency of better-educated personnel in distributing production inputs among the best alternative uses. Regardless of likely technical efficiency arising from firms' likelihood of producing physical units on their production possibility curve (PPC), workers possess greater awareness and make sound decisions on utilising marginal value product, that is, monetary units of inputs due to more knowledge of information availability (Ram, 1980). Hence, education reduces marginal costs while raising the marginal benefits of attaining associated manufacturing information. The research effect encompasses the relevance of higher education in research and development.

Developing human resources unarguably has a positive impact on the productive levels of industries notwithstanding that human capital theory is not particularly airtight. Unfortunately, despite several years of exploring industrialisation, many nations are still taking time to fully adapt key conceptualisations of industrial technology, resulting in low and lukewarm technological status. Numerous machines and capital structures being employed by factories are depreciated and worn-out, leading to inadequate yields and efficient capabilities which further makes possible repairs extremely arduous and often disrupts manufacturing processes. This is also evidenced in educational standards, mostly in top educational ranks where individuals are groomed to occupy leadership positions in business and management (Anumudu, 2010).

Thus, this paper builds on related studies that have explored the relevance of developing human capital (skills and abilities) and the various mechanisms - worker, allocative, research, consumption and investment effects either via formal, informal or self-development platforms - through which it aids production, industrialisation and efficiency of individuals, particularly in the labour force. Regardless of the different approaches undertaken by past studies, the non-negotiable role of human capital in boosting productivity and output levels is a general outcome. As such, the human capital theory will form the basis for designing the theoretical framework and methodology of this study.

\section{Methodology}

This study uses the World Enterprise 2014 Survey of the World Bank comprising a cross-section of manufacturing firms in Nigeria. This is the most recent survey period in terms of data availability. The micro-data analysis was analysed using the Spearman correlation technique.

\subsection{Theoretical and Schematic Framework}

Following the concept of Becker (1998), human capital comprising health, education and on-the-job trainings are basic requirements to heighten individuals' productivity. Worker (static) effect refers to productive values of education (Welch, 1970) which raises output per unit of schooling ceteris paribus. Meanwhile, the dynamic (allocative) educational effect represents an augmenting human capital (Bartel \& Lichtenberg, 1987). This involves the improvement of allocative expertise by training and learning as higher-educated people are better skilled to capitalise on up-to-date production avenues or modify existent methods to suit contemporary market trends compared to poorly educated and experienced personnel. Hence, such effectiveness emanates into greater quality commodities. The human capital theory negates the "screening hypothesis" which positions that education does not enhance the productivity of an individual but rather implicitly separates low-productive and high-productive individuals and thereafter classify them into befitting jobs. Nothwithstanding, more empirical evidence exists for human capital relative to the screening hypothesis given that human resources impact manufacturing output and overall growth via several mediums.

Notably, the signalling (Spence, 1973) or screening (Thurow, 1975) theories refute two key presumptions of human capital theory: deficit human capital (as demand always absorbs excess human capital) and perfect competition as there is a possibility of over-supply. Hence, education complemented by sound health, research and training activities are signs of a worker's capabilities and stakeholders classify education as a productive asset rather than a consuming product. More interestingly is the argument that high human capital engenders technology implementation based on the contention that skilled-labour augmenting technologies trigger productive gains of skilled workers unlike that of 
unskilled counterparts (Caselli \& Coleman, 2006). This is supported by neoclassical theories of international specialisation which considers human capital to be a production input, thereby propagating rigorous schooling for human-capital-related industries (Ciccone \& Papaioannou, 2009).

Thus, it is highly recommended that for an economy to maximise the gains from human capital, there must be at least $70 \%$ literate populace with minimum basic education. Notwithstanding, as posited by human capital theory, higher educational levels must be targeted for better efficiency. Hence, technology absorptions are proffered to make up for diminishing scale returns and ensure continuous national progressions (Anumudu, 2010). Adapting the schematic illustration of Anyanwu (2018) for the human capital-manufacturing linkage. Primary education provides unskilled labour for basic manufacturing; secondary education aids greater production dexterity; tertiary education enriches manufacturing industries with superior research and development levels for complex production operations.

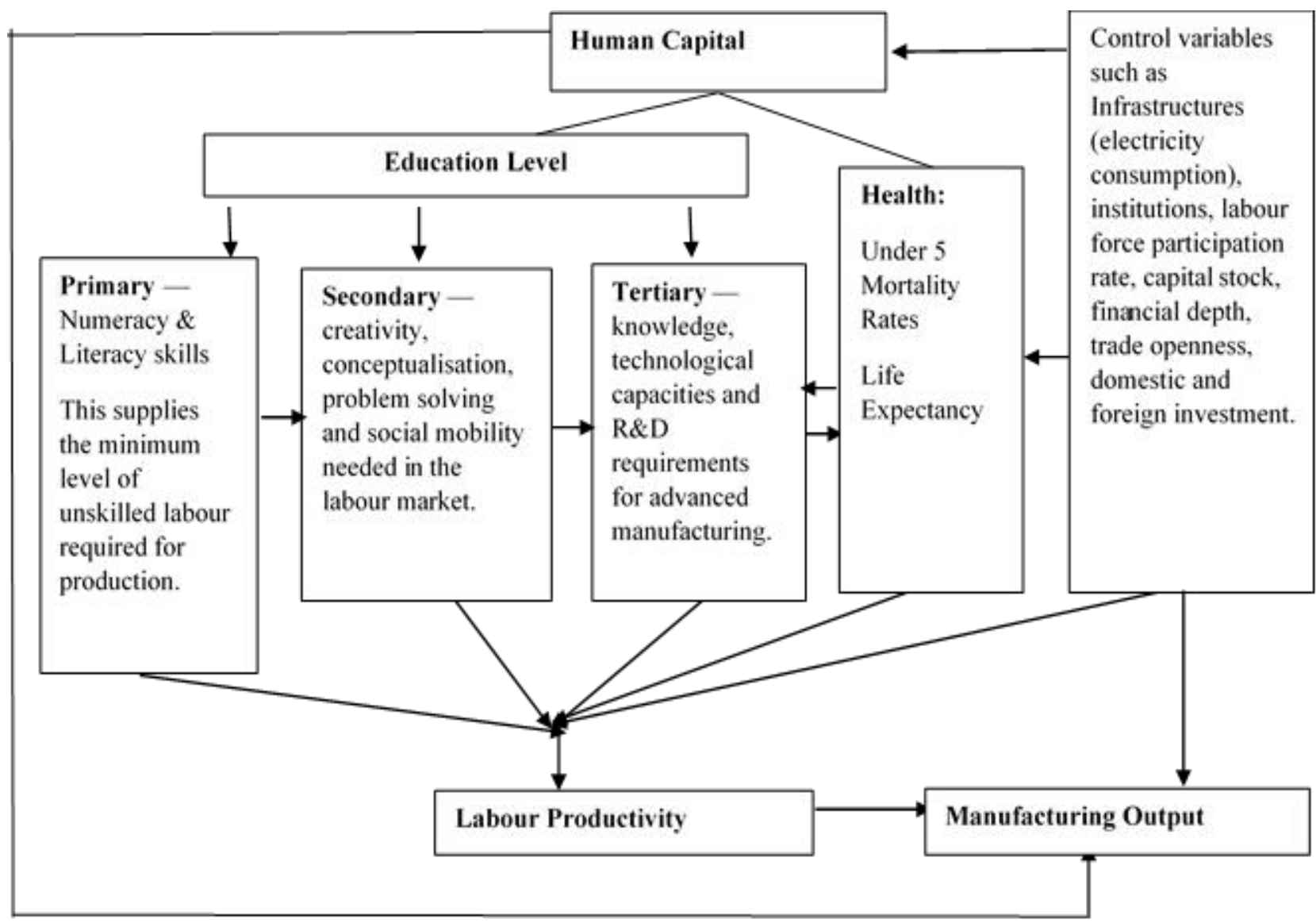

Figure 1. Schematic linkages between human capital and manufacturing

Description/Source: Education-Manufacturing Linkages adapted from Anyanwu (2018) and UNECA (2015).

\subsection{Model Specification and Expectations}

Following Anumudu (2010, 2018), this study specifies an implicit Cobb-Douglas production shown in equation [1]:

$$
Q_{\text {it }}=F\left(L_{\text {it }} K_{\text {it }} A_{\text {it }}\right) x=\frac{-b \pm \sqrt{b^{2}-4 a x}}{2 a}
$$

Where $Q=$ production value-added of firms; $L=$ labour; $K=$ capital stocks; $\mathrm{A}=$ technology; $\mathrm{i}=$ industry; $\mathrm{t}=$ time. As recognised by the European Commission (2009a, b), manufacturing output is determined by diverse sources as there is no one single theory that is exhaustive enough to elucidate the determining elements of manufacturing. Thus, 
equation [1] is modified to suit this paper's research framework and reflect the variables highlighted by the European Commission (2009a) alongside other empirical works such as Anyanwu (2018) who based his methodological framework/model on Haraguchi (2016). Correspondingly, equation [1] becomes:

$$
M V A_{\text {it }}=f\left(H C_{\text {it }}, X_{\text {it }}\right)
$$

Modifying equation [1] based on data availability from the Enterprise Survey (2014), the implicit model is:

$$
M V A=f(E D U, F O R M T R A I N, R D, X)
$$

Where HC $=$ EDU,FORMTRAIN, RD MVA $=f(E D U, F O R M T R A I N, R D, X)$ and the explicit model is specified as:

$$
M V A=\alpha_{0}+\alpha_{1} E D U+\alpha_{2} \text { FORMTRAIN }+\alpha_{2} R D+\alpha_{4} X+\mu
$$

And $\mathrm{X}$ is the row vector of control variables as indicated in equation [5]:

$$
\begin{aligned}
& \text { MVA }=\alpha_{0}+\alpha_{1} \text { EDU }+\alpha_{2} \text { FORMTRAIN }+\alpha_{2} R D+\alpha_{4} \mathrm{NPO}+\alpha_{5} \text { CSFIU }+\alpha_{6} \mathrm{CTR}+\alpha_{7} \text { WCBFB }+\mu \\
& \text { MVA }=\alpha_{0}+\alpha_{1} \text { FTWCHS }+\alpha_{2} \text { FORMTRAIN }+\alpha_{2} R D+\alpha_{4} \mathrm{NPO}+\alpha_{5} \text { CSFIU }+\alpha_{6} \mathrm{CTR}+\alpha_{7} \text { WCBFB }+\mu(5)
\end{aligned}
$$

Where EDU: Education - percentage (\%) of Full-time workers who completed high school;

FORMTRAIN: Percentage (\%) of Permanent Full-time production employees who received formal training;

$R D$ : what the establishment spent on formal Research \& Development activities in the last 3 years;

$N P O=$ proxy for infrastructure measured by electricity (Number of power outages experienced in a typical month);

$C S F I U=$ proxy for quality institutions measured by The Court System is fair, impartial and uncorrupted;

$C T R=$ proxy for trade openness represented by: How much of an obstacle: customs and trade regulations;

$W C B F B=$ proxy for financial depth measured by: Percentage of working capital borrowed from banks;

$\alpha_{0}$ is the intercept term; $\alpha_{1}, \alpha_{2}, \alpha_{3}$ and $\alpha_{4}, \alpha_{5}, \alpha_{6}, \alpha_{7}$ are the slope parameters; and $\mu$ is the disturbance (error) term.

\begin{tabular}{|c|c|}
\hline Variables & Definition and Measurement \\
\hline FTWCHS & $\begin{array}{l}\text { This represents full-time workers that have completed } \\
\text { high school to represent the educational component of } \\
\text { human capital. }\end{array}$ \\
\hline FORMTRAIN & $\begin{array}{l}\text { This captures the degree of formal training in } \\
\text { manufacturing enterprises as part of human capital } \\
\text { components. }\end{array}$ \\
\hline$R D$ & $\begin{array}{l}\text { Research and development are very essential to build a } \\
\text { highly knowledgeable workforce. }\end{array}$ \\
\hline NPO & $\begin{array}{l}\text { This reflects the average number of power outages that } \\
\text { establishments experience in a typical month. }\end{array}$ \\
\hline CSFIU & $\begin{array}{l}\text { Fair, impartial and uncorrupted courts serve as } \\
\text { governing institutions to facilitate a conducive } \\
\text { environment for smooth running of businesses. }\end{array}$ \\
\hline$C T R$ & $\begin{array}{l}\text { Customs and trade regulations can be reflective of the } \\
\text { degree of openness in a given economy for hitch-free } \\
\text { business transactions. }\end{array}$ \\
\hline$W C B F B$ & $\begin{array}{l}\text { Working capital borrowed from banks indicates the } \\
\text { level of financial depth. }\end{array}$ \\
\hline
\end{tabular}

On the a priori expectations, EDU, RD, NPO, CSFIU, and WCBFB are expected to be positive; NPO - that is, power failure should negatively impact manufacturing output while that of CTR is indeterminate. Table 1 gives the description and measurement of each variable used in the study.

Table 1. Variables definitions and measurements and sources

Description/Source: Authors' Compilations 


\section{Data Analysis and Presentation of Results}

\subsection{Univariate Analysis}

In this section, frequency distribution is carried out on specific socio-demographic characteristics of these surveyed manufacturing enterprises including sampling region, locality size, industry screener sector and other variables.

Table 2. Socio-demographic characteristics of selected industries

\begin{tabular}{|c|c|c|c|c|c|}
\hline Characteristics & Frequency & Percentage & Characteristics & Frequency & Percentage \\
\hline \multicolumn{3}{|l|}{ Region of the Establishment } & \multicolumn{3}{|l|}{ Industry Screener Sector } \\
\hline Abia & 124 & 4.63 & Food & 272 & 10.16 \\
\hline Abuja & 151 & 5.64 & Tobacco & 2 & 0.07 \\
\hline Anambra & 149 & 5.57 & Textiles & 47 & 1.76 \\
\hline Cross river & 136 & 5.08 & Garments & 164 & 6.13 \\
\hline Enugu & 124 & 4.63 & Leather & 28 & 1.05 \\
\hline Kaduna & 138 & 5.16 & Wood & 57 & 2.13 \\
\hline Kano & 200 & 7.47 & Paper & 7 & 0.26 \\
\hline Lagos & 282 & 10.54 & $\begin{array}{l}\text { Publishing, printing, and } \\
\text { Recorded media }\end{array}$ & 164 & 6.13 \\
\hline Оуо & 119 & 4.45 & Refined petroleum product & 14 & 0.52 \\
\hline Gombe & 126 & 4.71 & Chemicals & 39 & 1.46 \\
\hline Jigawa & 123 & 4.60 & Plastics \& rubber & 26 & 0.97 \\
\hline Katsina & 125 & 4.67 & Non-metallic mineral products & 182 & 6.80 \\
\hline Kebbi & 133 & 4.97 & Basic metals & 42 & 1.57 \\
\hline Kwara & 124 & 4.63 & Fabricated metal products & 152 & 5.68 \\
\hline Nasarawa & 130 & 4.86 & Machinery and equipment & 21 & 0.78 \\
\hline Niger & 124 & 4.63 & Electronics & 11 & 0.45 \\
\hline Ogun & 130 & 4.86 & Precision instruments & 4 & 0.14 \\
\hline Sokoto & 115 & 4.30 & Furniture & 191 & 7.14 \\
\hline Zamfara & 123 & 4.60 & Recycling & 3 & 0.11 \\
\hline \multicolumn{3}{|c|}{ Is this city the main business city? } & Construction & 52 & 1.94 \\
\hline Yes & 1,083 & 40.47 & Services of motor vehicles & 180 & 6.73 \\
\hline No & 1,593 & 59.53 & Wholesale & 153 & 5.72 \\
\hline \multicolumn{3}{|l|}{ Size of Locality } & Retail & 451 & 16.85 \\
\hline $\begin{array}{l}\text { City with over } 1 \text { million } \\
\text { population }\end{array}$ & 1,503 & 56.17 & Hotel and restaurants & 247 & 9.23 \\
\hline Over 250,000 to 1 million & 831 & 31.05 & Transport Section & 166 & 5.21 \\
\hline 50,000 to 250,000 & 297 & 11.10 & \multicolumn{3}{|l|}{ Legal Status of the Firm } \\
\hline Less than 50,000 & 45 & 1.68 & $\begin{array}{l}\text { Shareholding company with } \\
\text { shares trade in the stock market }\end{array}$ & 91 & 3.49 \\
\hline \multicolumn{3}{|l|}{ Sampling Size } & $\begin{array}{l}\text { Shareholding company with } \\
\text { non-traded shares }\end{array}$ & 121 & 4.64 \\
\hline Micro $<5$ & 316 & 11.81 & Sole proprietorship & 2,007 & 76.99 \\
\hline Small $>=5$ and $<=19$ & 1,395 & 52.13 & Partnership & 189 & 7.25 \\
\hline Medium $>=20$ and $<=99 \mid$ & 740 & 27.65 & Limited partnership & 164 & 6.29 \\
\hline Large $>=100$ & 225 & 8.41 & Other (Spontaneous-Specify) & 35 & 1.34 \\
\hline
\end{tabular}

Description/Source: Authors' Compilations 
From Table 2, Lagos and Kano have the highest number of respondents with over $10 \%$ and $4.3 \%$ respectively. Cities with over 1 million people represented more than $50 \%$ of the sample. Sizes of most enterprises within the sample area are small businesses. Retail ventures followed by food businesses occupied the greatest majority of industries. Interestingly, approximately $77 \%$ of respondents are sole proprietors.

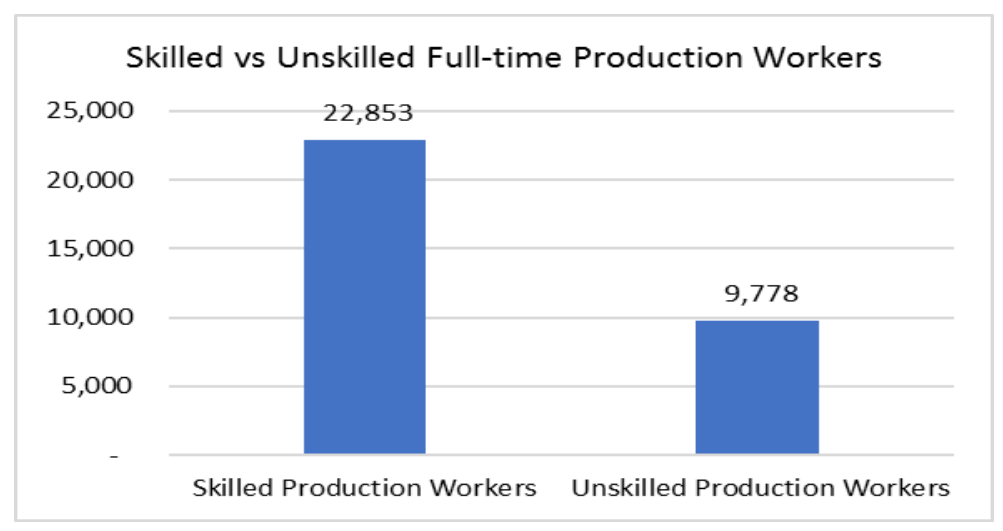

Figure 2a. Full-time employees in production at the end of fiscal year: Skilled vs unskilled

Description/Source: Authors' Compilations

From the above bar chart in figure 2a, the skilled and unskilled production workers represent $70 \%$ and $30 \%$ of the entire 32,631 full-time employees that constitute the labour force in manufacturing enterprises. Hence, it can be deduced that the proportion of skilled workers have relatively increased over time, although there is still room for more improvement.

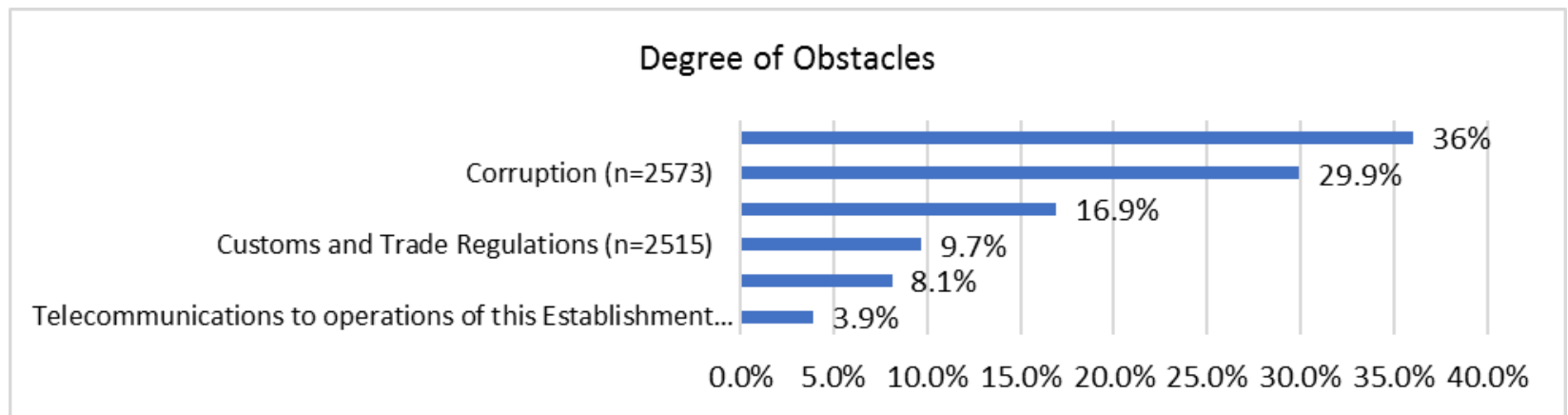

Figure 2b. Degree of obstacles against manufacturing output

Description/Source: Authors' Compilations

Figure $2 \mathrm{~b}$ reflects that electricity constitutes the largest volume of obstacles compared to others. This is closely followed by corruption which can be deciphered from the efficiency of institutions. Access to finance constitutes the third biggest barrier. Poorly educated workforce, labour regulations and telecommunications appear to constitute the least of obstacles relative to others. 


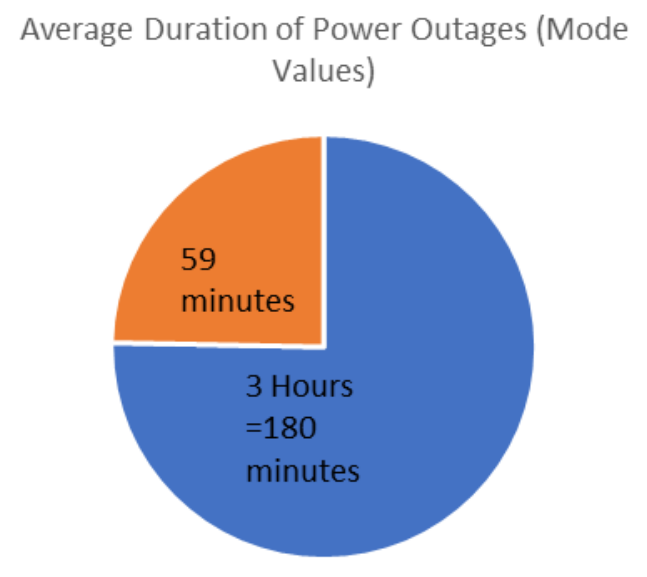

- Average duration of power outages: Hours

- Average duration of power outages: Minutes

Figure 2c. Average duration of power outages: Hours vs minutes

Description/Source: Authors' Compilations

From Figure 2c, it is indicated that the average duration of electricity in hours surpasses that of minutes. This reflects the frequency of the magnitude and length of power failure that is often experienced by manufacturing firms.

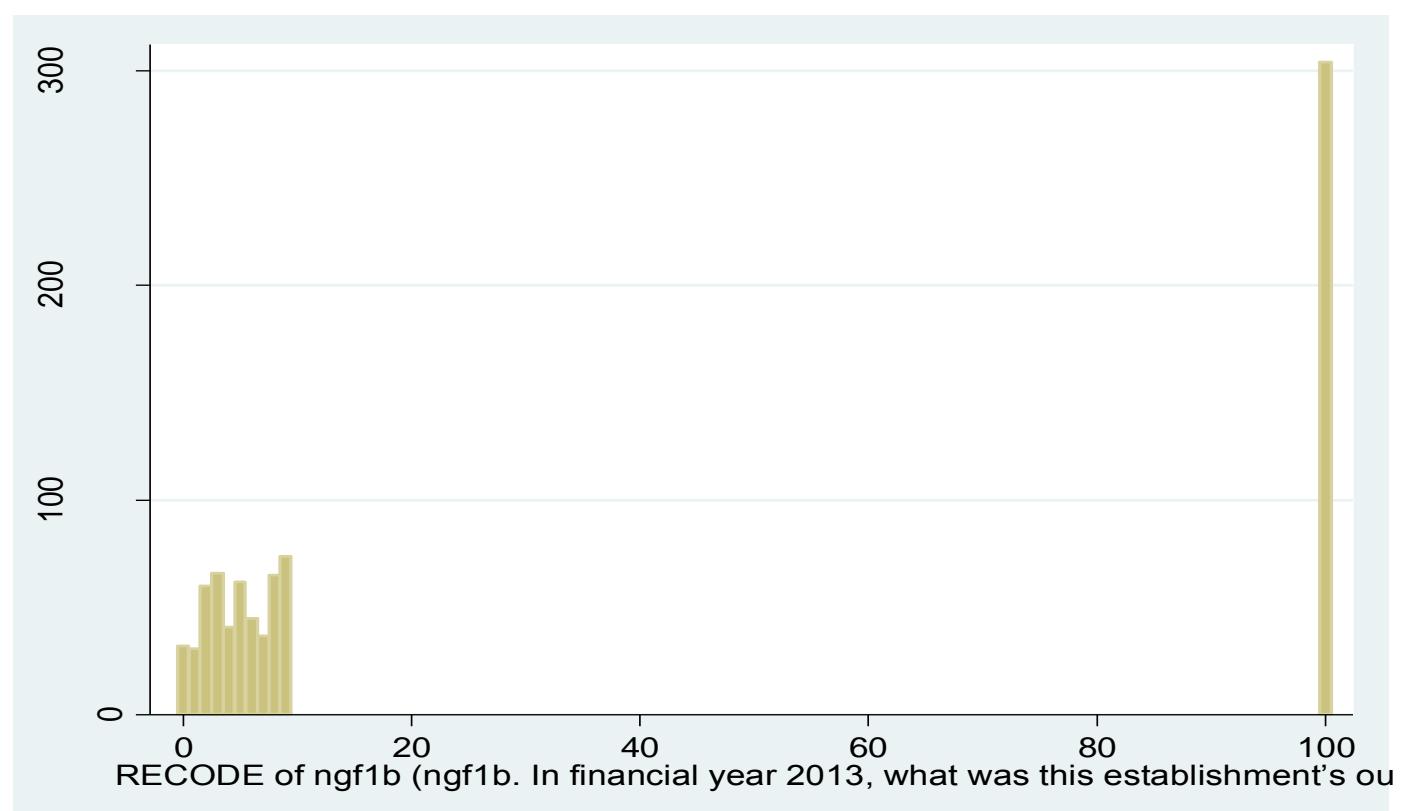

Figure 2d. Level of manufacturing output (\%)

Description/Source: Authors' Compilations

From the histogram shown in Figure 4, it is apparent that the most frequent volume of manufacturing output (as a percentage) occurred in the category of less than $20 \%$ whereas just a very scanty number of respondents made up to $100 \%$ output. 


\subsection{Bivariate Analysis: Cross Tabulation}

Cross-tabulation is carried out on the dependent variable (level of manufacturing output) and some selected key independent variables as seen in Table 3.

Table 3. Cross tabulation of dependent and key independent variables

\begin{tabular}{|c|c|c|c|c|c|c|}
\hline & \multicolumn{6}{|c|}{ What was the establishment's output produced as a percentage? } \\
\hline & $\mathbf{0 - 2 0 \%}$ & $21-40 \%$ & $41-60 \%$ & $61-80 \%$ & $81-100 \%$ & $\begin{array}{l}\text { Pearson } \\
\text { Chi-squar } \\
\text { e }\end{array}$ \\
\hline \multicolumn{7}{|c|}{ \% of full-time workers completed high school? } \\
\hline $0-20 \%$ & 28.57 & 22.18 & 14.29 & 7.14 & 27.82 & \multirow{5}{*}{$\begin{array}{l}154.2177 \\
(0.000)\end{array}$} \\
\hline $21-40 \%$ & 10.00 & 16.00 & 10.00 & 12.00 & 52.00 & \\
\hline $41-60 \%$ & 9.68 & 18.28 & 18.28 & 10.75 & 43.01 & \\
\hline $61-80 \%$ & 5.71 & 5.71 & 14.29 & 21.90 & 52.38 & \\
\hline $81-100 \%$ & 4.76 & 4.33 & 10.39 & 14.72 & 65.80 & \\
\hline \multicolumn{7}{|c|}{$\begin{array}{l}\text { During the last three years, did the } \\
\text { establishment spend on formal R\&D activities: }\end{array}$} \\
\hline Yes & 19.77 & 12.43 & 17.51 & 10.73 & 39.55 & \multirow{2}{*}{$\begin{array}{l}9.3713 \\
(0.052)\end{array}$} \\
\hline No & 13.79 & 13.47 & 11.89 & 13.00 & 47.86 & \\
\hline \multicolumn{7}{|c|}{$\begin{array}{l}\% \text { of full-time production employees received } \\
\text { formal training in the last Fiscal year: }\end{array}$} \\
\hline $0-20 \%$ & 28.95 & 19.74 & 30.26 & 6.58 & 14.47 & \multirow{5}{*}{$\begin{array}{l}73.7055 \\
(0.000)\end{array}$} \\
\hline $21-40 \%$ & 25.00 & 25.00 & 10.71 & 17.86 & 21.43 & \\
\hline $41-60 \%$ & 17.14 & 17.14 & 17.14 & 14.29 & 34.29 & \\
\hline $61-80 \%$ & 8.70 & 17.39 & 17.39 & 8.70 & 47.83 & \\
\hline $81-100 \%$ & 5.13 & 5.13 & 6.41 & 12.82 & 70.51 & \\
\hline \multicolumn{7}{|c|}{$\begin{array}{l}\text { The Court System is fair, impartial and } \\
\text { uncorrupted: }\end{array}$} \\
\hline Strongly disagree & 21.19 & 16.95 & 12.71 & 14.41 & 34.75 & \multirow{4}{*}{$\begin{array}{l}19.2812 \\
(0.082)\end{array}$} \\
\hline Tend to disagree & 15.79 & 12.87 & 8.77 & 14.04 & 48.54 & \\
\hline Tend to agree & 12.08 & 15.44 & 16.11 & 13.42 & 42.95 & \\
\hline Strongly agree & 15.95 & 8.59 & 12.27 & 12.27 & 50.92 & \\
\hline \multicolumn{7}{|c|}{$\begin{array}{l}\text { Number of power outages experienced in a } \\
\text { typical month: }\end{array}$} \\
\hline $0-500$ & 13.78 & 13.99 & 14.61 & 13.99 & 43.63 & \multirow{4}{*}{$\begin{array}{l}17.4370 \\
(0.026)\end{array}$} \\
\hline $501-1000$ & 20.00 & 40.00 & 20.00 & 0.00 & 20.00 & \\
\hline $1001-1500$ & - & - & - & - & - & \\
\hline $1501-2000$ & 75.00 & 0.00 & 25.00 & 0.00 & 0.00 & \\
\hline \multicolumn{7}{|c|}{$\begin{array}{l}\text { How much of an obstacle: customs and trade } \\
\text { regulations? }\end{array}$} \\
\hline No obstacle & 13.48 & 13.11 & 11.99 & 13.86 & 47.57 & \\
\hline Minor & 13.78 & 11.81 & 11.02 & & & 22.7976 \\
\hline
\end{tabular}




\begin{tabular}{lllllll}
\hline Moderate & 14.55 & 16.36 & 16.36 & 15.35 & 48.03 & $(0.119)$ \\
Major & 26.83 & 14.63 & 14.63 & 10.30 & 42.42 & \\
Very Severe & 22.22 & 11.11 & 33.33 & 8.54 & 35.37 & \\
& & & & 11.11 & 22.22 & \\
\% of working capital borrowed from banks: & & & & & & \\
$0-20 \%$ & 14.98 & 12.69 & 12.96 & 12.82 & 46.56 & 23.9793 \\
$21-40 \%$ & 24.32 & 16.22 & 2.70 & 10.81 & 45.95 & $(0.090)$ \\
$41-60 \%$ & 0.00 & 12.50 & 12.50 & 37.50 & 37.50 & \\
$61-80 \%$ & 0.00 & 0.00 & 66.67 & 0.00 & 33.33 & \\
$81-100 \%$ & 50.00 & 50.00 & 0.00 & 0.00 & 0.00 & \\
\hline
\end{tabular}

Description/Source: Authors' Compilations

From Table 3, the highest category of individuals with completed high school education (81-100\%) account for the largest proportion ( $65 \%$ of output) while the lowest combination of workers with high-school education contributed the least to output. This is identical to the classification of those full-time employees who received formal training. For research activities, it seems that firms that spent on $R \& D$ operations have a lower peak of manufacturing output compared to those who did not. This may be attributed to the fact that R\&D takes a while to yield optimum effects or could be suggestive of relatively inadequate $\mathrm{R} \& \mathrm{D}$ equipment given that the questionnaire did not capture the degree of research instruments.

Majority of the participants strongly agree that the court system is rather biased and inefficient which speaks poorly of the quality of institutions in Nigeria. The number of power outages within the range of 1501-2000 account for 75 percent of the lowest output category (0-20\% of MVA) while electricity failure within the frequency of 0-500 affects about $43.6 \%$ of the highest output category. The highest category of manufacturing output (48.03) shows customs and trade regulations to be a minor obstacle. However, that same highest MVA reduces when the customs and trade regulation become more severe (22.22). Similarly, the highest category of manufacturing output (at almost 50\%) borrows the least from banks at $0-20 \%$ lending of working capital. However, those who borrow up to $50 \%$ of their working capital from banks fall within the classification of $0-40 \%$ output. This indicates that excessive borrowing especially under unfavourable situations and high rates could be detrimental to business outputs. Rejecting the null hypothesis at the $10 \%$ level, that the Pearson chi-square shows the statistical significance at the $1 \%, 5 \%$, and $10 \%$ levels, respectively for all indicators except customs and trade regulations.

\subsection{Spearman Correlation Matrix}

This section presents the correlation matrix to show the direction, magnitude and significance of the relationships. From Table 4, the correlation coefficient between manufacturing output and the explanatory variables reveal the following: the correlation coefficient of high-school education (0.395) depicts a statistically significant positive relationship at the $1 \%$ level; a statistically significant positive relationship exists with formal training given the coefficient of 0.495 which is significant at the $1 \%$ level; formal research activities shows a positive association (0.08) that js statistically significant at the 5\% level; impartial nature of court systems/institutions is also positive $(0,076)$ and statistically significant at the $5 \%$ level; the coefficnt on power outages is negative $(-0,127)$ and statistically significant at the $1 \%$ level; customs and trade regulations show a negative $(-0.095)$ and statistically significant relation at the $1 \%$ level; lastly, working capital from banks $(-0.032)$ is negative not statistically not significant.and manufacturing output show a low but statistically negative relationship. These outcomes are discussed in detail in Section 5. 
Table 4. Spearman correlation matrix

\begin{tabular}{lcc}
\hline Variables & MAN Output & No. of Obs. \\
\hline Level of MAN Output & 1.000 & \\
Full-time Workers Completed High School & $0.395^{* * *}$ & 745 \\
Formal Training & $0.495^{* * *}$ & 240 \\
Formal R\&D activities & $0.080^{* *}$ & 808 \\
Impartiality of Courts System & $0.076^{* *}$ & 750 \\
Number of Power Outages & $-0.127^{* * *}$ & 488 \\
Customs \& Trade Regulations & $-0.095^{* * *}$ & 777 \\
Working Capital from Banks & -0.032 & 791 \\
\hline
\end{tabular}

Note: $* * *, * *$, and $*$ indicate statistical significance at the $1 \%, 5 \%$, and $10 \%$ levels, respectively.

Source: Authors' Computations

\section{Discussion}

From Table 4, nothwithstanding the statistical significance at the $1 \%$ and $5 \%$ levels, respectively, the indicators of human capital - high-school education, formal training and R\&D - show that, in terms of magnitude, they have a rather low positive impact on the output of manufacturing firms. This supports Adejumo, Olomola and Adejumo (2013) and Kurre and Eiben (2013) with several implications. The first response might be to dispute the fact that education as a component of human capital is irrelevant for manufacturing enterprises since it seems to be adversely affecting the sector. These outcomes support theoretical postulations that affirm the importance of a highly educated workforce on productivity and output levels. Moreover, several empirical evidences exist of how education has to a great extent bridged the gap in helping many developed countries get to their advanced states given proper and responsible utilization (Alam, Forhad \& Ismail, 2020; Ozdemir, 2020).

However, in although th effect of human capital on manufacturing outout is positive, it is a rather low magnitude with potential for much better performance. This implies that Nigeria generally has poorly skilled human resources in terms of limited knowledgeability, training, exposure and dexterity, stemming from the basic foundation of education, ranging from primary to tertiary schools. However, given the high rate of enrolment rate and numerous schools in the country, with primary schools taking the majority number, followed by secondary and tertiary institutions, the issue is not necessarily enrolment of students. Also, Nigeria has made several education efforts such as Basic Education Schemes that have been quite successful in terms of enrolment and affordability. So, this illuminates that educational quantity in form of enrolment rate is not so low and has been on the rise over time.

The less likelihood of buoyant educational quantity in explaining the rather minute positive effect of education on manufacturing output leads us to consider the more likely cause, which is the quality of education. This is evident via indicators such as completion rate which is highly crucial because not everyone that gets enrolled is able to graduate, owing to several reasons including high drop-out rates, economic hardship and child labour (mostly for females although this has reduced considerably due to globalisation). Thus, the proportion of graduates is often times not proportional to the volume of students who were enrolled in the first place. Another measure of education quality is training, rigorous research activities, practical exposure to real-life and hands-on issues rather than just theoretical discourses in the classroom, of which the latter is prevalent within the African continent as many students read just to pass (otherwise known as the diploma disease) (Oforegbunam \& Okorafor, 2010; Dore, 1997). All these qualitative approaches are generally lacking among Nigerian firms. Hence, it is not surprising that the educational quality is poor despite its large quantity given that it is these qualitative measures that really make a difference in terms of acquiring knowledge, skilfulness and experience such that efficiency and output levels will be boosted, particularly for the manufacturing sector. This signifies that there is greater room for a lot of improvement in Nigeria's education and health sector, particularly since the former tends to be time-dependent as observed by Anyanwu (2018), especially in relation to manufacturing industries.

\section{Conclusion and Recommendations}

This study explores the impact of human capital on manufacturing output among Nigerian firms. Variables from the 
World Bank (2014) Enterprise Survey (WBES) are used for micro-data analysis. Based on the research objective, descriptive statistics, cross-tabulation and Spearman correlation matrix techniques are implemented. The results show that high-school education, formal training and R\&D have low magnitude but statistically significant positive impact on the output of manufacturing firms. This may be attributed to the poor standards and quality of education, lacking skills, knowledgeability, inadequate trainings, exposure and dexterity, most likely stemming from the high drop-out rates, economic hardship and poor conducive environment for workers in general.

The policy recommendations emanating from this study are as follows: (1) There is the need for greater intensity of training and research and development (R\&D) activities not just at workplaces but starting from the classroom via entrepreneurial ventures and hands-on exposure. (2) Collaborative partnerships between public and private enterprises should be encouraged and educational schemes re-structured to be much more practical than theoretical. This will help to improve human capital quality and advancement towards SDG 9.5 and subsequently industrialisation targets of SDG 9.2. (3) Fostering a more conducive business environment via efficient institutions (rule of law, governance, corruption, fairness, accountability and regulatory quality). That is, when business operations become easier, straightforward and less bureaucratic to execute, they stimulate friendly competitiveness among numerous manufacturing enterprises.

Given some constraints such as inability to carry out an actual field survey using instruments such as questionnaires, in-depth interviews (IDI), focus group discussions (FGDs), among others, due to limited resources (funds, and sufficient manpower) required to move across various manufacturing firms within Nigeria. Also, the research was somewhat limited in terms of using more recent data such as that of 2019 due to data availability. In light of this, future studies might consider doing a country-based fieldwork survey, possibly for Nigeria and other developing or emerging nations given the availability of resources to engage the analysis with improved precision.

\section{Acknowledgements}

Authors appreciate the Covenant University Centre for Research, Innovation and Discovery (CUCRID) for funding the publication of this research.

\section{References}

Adejumo, A. V., Olomola, P. A., \& Adejumo, O. O. (2013). The Role of Human Capital in Industrial Development: The Nigerian Case (1980-2010). Modern Economy, 4(10). https://doi.org/10.4236/me.2013.410069

Adeleye, N., Osabuohien, E., \& Asongu, S. (2020). Agro-Industrialisation and Financial Intermediation in Nigeria. African Journal of Economic and Management Studies. https://doi.org/10.1108/AJEMS-02-2019-0078

Adenikinju, A., Söderling, L., Soludo, C., \& Varoudakis, A. (2002). Manufacturing Competitiveness in Africa: Evidence from Cameroon, Côte d'Ivoire, Nigeria, and Senegal. Economic Development and Cultural Change, 50(3), 643-665. https://doi.org/10.1086/342423

Adesugba, M., \& Mavrotas, G. (2016). Youth Employment, Agricultural Transformation, and Rural Labor Dynamics in Nigeria. International Food Policy Research Institute (IFPRI), Discussion Paper 01579; Development Strategy and Governance Division.

Alam, G. M., Forhad, A. R., \& Ismail, I. A. (2020). Can education as an 'International Commodity'be the backbone or cane of a nation in the era of fourth industrial revolution? - A Comparative study. Technological Forecasting and Social Change, 159, 120184. https://doi.org/10.1016/j.techfore.2020.120184

Anumudu, C. N. (2010). The impact of human capital on labour Productivity in manufacturing industries in Enugu and Anambra states, Nigeria. A Ph. D Thesis Dissertation Submitted to the Department of Economics, University of Nigeria.

Anyanwu, J. C. (2018). Does Human Capital Matter in Manufacturing Value Added Development in Africa?. Asian Journal of Economic Modelling, 6(3), 294-317. https://doi.org/10.18488/journal.8.2018.63.294.316

Arrow, K. J. (1962). The Economic Implications of Learning by Doing. Review of Economic Studies 29, 155-173. https://doi.org/10.2307/2295952

Ash, R. (1988). Job analysis in the world of work. In S. Gael (Ed.), The job analysis handbook for business, industry and government, 1 . New York: John Wiley.

Bartel, A. P., \& Lichtenberg, F. R. (1987). The Comparative Advantage of Implementing New Technology. Review of Economics and Statistics, 69(1), 1-11. https://doi.org/10.2307/1937894

Becker, G. (1964). Human Capital: A Theoretical and Empirical Analysis with Special Reference to Education (3rd 
ed. 1993). Chicago and London: The University of Chicago Press. https://doi.org/10.7208/chicago/9780226041223.001.0001

Becker, G. S. (1998). Human capital and poverty. Religion and Liberty, 8(1), 5-7.

Braverman, H. (1974). Labor and Monopoly Capital. New York: Monthly Review Press. https://doi.org/10.14452/MR-026-03-1974-07_1

British Broadcasting Corporation - BBC. (2017). Nigeria has 'largest number of children out-of-school' in the world. Retrieved May 20, 2020, from https://www.google.com/amp/s/www.bbc.com/news/amp/world-africa-40715305

Caselli, F., \& Coleman, A. (2006). The world technology frontier. American Economic Review, 96(3), 499-522. https://doi.org/10.1257/aer.96.3.499

Ciccone, A., \& Papaioannou, E. (2009). Human capital, the structure of production, and growth. The Review of Economics and Statistics, 91(1), 66-82. https://doi.org/10.1162/rest.91.1.66

Cörvers, F. (1994). Human capital factors at the firm level. ROA Working Papers (7E).

Crafts, N. (2018). The productivity slowdown: is it the 'new normal'?. Oxford Review of Economic Policy, 34(3), 443-460. https://doi.org/10.1093/oxrep/gry001

De Vries, G., Timmer, M., \& De Vries, K. (2015). Structural transformation in Africa: Static gains, dynamic losses. The Journal of Development Studies, 51(6), 674-688. https://doi.org/10.1080/00220388.2014.997222

Dore, R. (1997). Reflections on the diploma disease twenty years later. Assessment in Education, 4(1), 189-206. https://doi.org/10.1080/0969594970040113

European Commission. (2009a). European competitiveness report 2008. Luxembourg: European Commission.

European Commission. (2009b). Sectoral growth drivers and competitiveness in the European Union. Luxembourg: European Commission.

Fallon, P., \& Lucas, R. (1998). South African Labor Markets, Adjustment and Inequalities. Informal Discussion Papers on Aspects of the South African Economy, (12).

Frankema, E. (2015). Labour-intensive industrialization in global history: a review essay. Economic History of Developing Regions, 30(1), 44-67. https://doi.org/10.1080/20780389.2015.1035705

Haraguchi, N. (2016). Patterns of manufacturing change and structural development. In Weiss, J., \& Tribe, M. A. (Eds.), Routledge handbook of industry and development. Abingdon and New York: Routledge.

Howell, D. R., \& Wolf, E. N. (1991). Trends in the Growth and Distribution of Skills in the U.S. Workplace, 1960-1985. Industrial and Labor Relations Review, 44(3), 486-502. https://doi.org/10.1177/001979399104400306

Kurre, J. A., \& Eiben, D. F. (2013). Determinants of labor productivity for detailed manufacturing industries. Economic Research Institute of Ere.

Lall, S. (1998). Technology and human capital in maturing Asian countries. Science, Technology and Society, 3(1), 11-48. https://doi.org/10.1177/097172189800300102

Maroto-Sánchez, A., \& Cuadrado-Roura, J. R. (2009). Is growth of services an obstacle to productivity growth? A comparative analysis. Structural Change and Economic Dynamics, 20, 254-265. https://doi.org/10.1016/j.strueco.2009.09.002

Meagher, K. (2016). The scramble for Africans: Demography, globalisation and Africa's informal labour markets. The Journal of Development Studies, 52(4), 483-497. https://doi.org/10.1080/00220388.2015.1126253

National Bureau of Economic Research. (2020). The Economic Decline in Africa. Retrieved from https://www.nber.org/digest/jan04/w9865.html

Nwokeocha, S. (2018). Right to Education and Teacher Gap in Nigeria: Estimating the Problem and Lessons from International Best Practices. Advances in Social Sciences Research Journal, 5(10). https://doi.org/10.14738/assrj.510.5415

Oforegbunam, E. T., \& Okorafor, G. T. (2010). Effects of human capital development on the performance of small \& medium scaled enterprises in the Southeastern Region of Nigeria. Journal of Sustainable Development in Africa, 12(8), 49-58. 
Ogunleye, O. O., Owolabi, O. A., Sanyaolu, O. A., \& Lawal, O. O. (2017). Human capital development and economic growth in Nigeria. Journal of Business Management, 3(8), 17-37.

Onakoya, A. B. (2014). Contributions of manufacturing in the context of inter-sectoral linkages to economic growth in Nigeria. Ago Iwoye Journal of Social and Behavioual Sciences, 3(1), 81-105.

Ozdemir, O. (2020). Distributional Effects of Human Capital in Advanced Economies: Dynamics of Economic Globalization. Business and Economics Research Journal, 11(3), 591-607. https://doi.org/10.20409/berj.2020.271

Page, J. (2018). The Road not Taken: Structural Change in Africa Reconsidered. In Foresight Africa: Top Priorities for the Continent in 2018. Washington DC: Brookings Institution.

Pencavel, J. (1991). Higher Education, Productivity and Earnings: A Review. Journal of Economic Education, 22, 331-359. https://doi.org/10.1080/00220485.1991.10844727

Ram, R. (1980). Role of Education in Production: A Slightly New Approach. Quarterly Journal of Economics, 94, 365-373. https://doi.org/10.2307/1885505

Schultz, T. W. (1961a). Investment in human capital. American Economic Review, 51(1), 1-17.

Shaffer, H. G. (1961). Investment in human capital: Comment. America Economic Review, 51(5), 1026-1034.

Spence, M. (1973). Job market signaling. Quarterly Journal of Economics, 87, 355-74. https://doi.org/10.2307/1882010

Stevens, M. (1994). An investment model for the supply of training by employers. The Economic Journal, 104, 556-570. https://doi.org/10.2307/2234631

Thirlwall, A. P. (2013). Commentary on Kaldor's 1970 regional growth model. Scottish Journal of Political Economy, 60(5), 492-494. https://doi.org/10.1111/sjpe.12027

Thurow, L. (1975). Generating Inequality: Mechanisms of Distribution in the U.S. Economy. New York: Basic Books. https://doi.org/10.1007/978-1-349-15723-5

UNECA, A. (2015). AfDB and UNDP (2015). MDG Report 2015: Assessing Progress in Africa toward the Millennium Development Goals.

UNIDO. (2015). Industrial development report 2016: The role of technology and innovation in inclusive and sustainable industrial development. Vienna: UNIDO.

Welch, F. (1970). Education in production. Journal of Political Economy, 78, 35-59. https://doi.org/10.1086/259599

\section{Copyrights}

Copyright for this article is retained by the author(s), with first publication rights granted to the journal.

This is an open-access article distributed under the terms and conditions of the Creative Commons Attribution license (http://creativecommons.org/licenses/by/4.0/). 